\title{
RELATIONSHIPS BETWEEN PRODUCERS AND PROCESSORS IN TERMS OF FRUIT PRODUCTION AND PRICES OF FRUITS FOR PROCESSING IN POLAND
}

\author{
Sylwia Kierczyńska ${ }^{\bowtie}$ \\ Poznań University of Life Sciences, Poland
}

\begin{abstract}
The aim of this paper is to present the relationships between the growers and the processors in the supply chain of raw material for processing in Poland and to study the dependence between the level of purchase prices for individual species of fruit for processing and the harvest of these fruits in Poland. The investigations cover the period of 2000-2017. The object of the research were the volume of production and the prices of selected species of the fruits for processing (apples, sour cherries, plums, raspberries, strawberries, currants and gooseberries). The volume of fruit production were determined based on the data of the Central Statistical Office. Purchase prices of fruits for processing were adopted based on data of the Department of Horticulture Economics IERiGŻ-PIB. The dependence was studied by Pearson's correlation coefficient and Spearman's R index. Based on the literature review, among the factors important in relationships between producers of agricultural raw materials and processors can be mentioned: price volatility of the fruits for processing, small production scale, requirement of stable supply, and the ability to impact the quality of the raw materials for processing. The fragmentation of fruit production in Poland makes the small scale of fruit production contributes to the poor (the underlying) fruit growers' position in the supply chain of fruit for processing. Fruit producers must accept the terms of the sale and the price of fruits determined by fruit processing industry. The price for most (aside from the raspberries) species of fruit for processing in Poland were negative correlated with the amount of production while the negative sign shows that the increase in fruit harvest was accompanied by the decrease in purchase price of fruit for processing. The results suggest fruit growers the opportunity of impact on price of fruit for processing by controlling the volume of fruit harvest.
\end{abstract}

Keywords: supply chain, fruit for processing, fruit production, prices of fruit

\section{INTRODUCTION}

Poland is one of the largest world producers of such fruit as currants, apples, sour cherries, raspberries, gooseberries and chokeberries, as well as a major world producer of strawberries. A considerable proportion of fruit produced in Poland is used in processing - according to the Central Statistical Office (GUS, 2013) it accounted for $33 \%$ harvested plums, $72 \%$ sour cherries, $81 \%$ raspberries, $85 \%$ currants, $86 \%$ gooseberries and $36 \%$ apples (GUS, 2018). For this reason the fruit and vegetable industry plays a significant role in the distribution chain on the fruit market in Poland. For many years the economic and financial standing of fruit and vegetable processing industry in Poland has been good (Wiśniewska, 2011), with the industry developing technologically; since the largest processing plants are located in the fruit growing regions they are in the immediate vicinity of an abundant raw material base.

According to GUS (2012-2018) in Poland almost 150 thousand of farms are engaged in fruit production. Due to a considerable fragmentation of fruit production in Poland and the location of many orchards at a considerable distance from processing plants these plants are supplied by intermediaries, i.e. fruit purchasing 
companies (the so-called collection centres). In a situation when fruits are delivered by growers to the collection centres, fruit growers have no direct contact with the final consignee or buyer of fruit for processing, in this case the processing plant. In view of the above a question arises on the type and character of relationships between fruit growers and the fruit and vegetable industry. The primary aim of this study is to present the relationships between the growers and the processors in the supply chain of raw material for processing in Poland.

Fruit growers enter into interactions with processors in the fruit and vegetable industry in the period of fruit sales. Producers of fruit (particularly soft fruit) have a perishable product, which has to be sold within the shortest possible time after harvest to preserve the quality of fruit. Fruit and vegetable processors need raw material to produce processed fruit products, and the raw material such as soft fruit needs to be purchased immediately after harvest so that the fruit is of the highest possible quality. Problems faced when the two elements in the fruit distribution chain meet and they are related with purchase prices of fruit for processing. Protests of fruit growers are observed in a situation when in their opinion purchase prices of fruit for processing are too low. For this reason the secondary aim of the research was to study the dependence between the level of purchase prices for individual species of fruit for processing and the harvest of these fruits in Poland.

\section{ORGANISATION OF FRUIT PRODUCTION IN POLAND}

In Poland the total orchard area increased from 364 thousand ha in 2003 to 431 thousand ha in 2012, followed by a successive decrease in area (Table 1). The increase was observed mainly in the area cropped to berry shrubs

Table 1. The area of fruit production and the number of farms with orchards in Poland in the period 2000-2017

\begin{tabular}{|c|c|c|c|c|}
\hline \multirow[b]{2}{*}{ Item } & \multicolumn{3}{|c|}{ The area of fruit-bearing trees and shrubs cultivation (ha) } & \multirow{2}{*}{$\begin{array}{c}\text { The number of farms with } \\
\text { orchards }\end{array}$} \\
\hline & Total & $\begin{array}{l}\text { The area of fruit-bearing trees } \\
\text { cultivation }\end{array}$ & $\begin{array}{c}\text { The area of fruit shrubs and } \\
\text { strawberries cultivation }\end{array}$ & \\
\hline 2000 & 394.3 & 276.9 & 117.4 & $\mathrm{n} / \mathrm{a}$ \\
\hline 2001 & 401.6 & 278.9 & 122.7 & $\mathrm{n} / \mathrm{a}$ \\
\hline 2002 & 375.9 & 271.9 & 104.0 & 260389 \\
\hline 2003 & 364.0 & 258.3 & 105.7 & $\mathrm{n} / \mathrm{a}$ \\
\hline 2004 & 390.4 & 275.2 & 115.2 & $\mathrm{n} / \mathrm{a}$ \\
\hline 2005 & 386.9 & 256.7 & 130.2 & $\mathrm{n} / \mathrm{a}$ \\
\hline 2006 & 380.6 & 255.1 & 125.5 & 274905 \\
\hline 2007 & 417.5 & 286.7 & 130.8 & 276693 \\
\hline 2008 & 409.0 & 279.8 & 129.2 & $\mathrm{n} / \mathrm{a}$ \\
\hline 2009 & 409.9 & 281.9 & 128.0 & $\mathrm{n} / \mathrm{a}$ \\
\hline 2010 & 410.2 & 279.5 & 130.7 & 284120 \\
\hline 2011 & 428.7 & 296.3 & 132.4 & 215100 \\
\hline 2012 & 431.7 & 295.4 & 136.3 & 198300 \\
\hline 2013 & 424.9 & 278.2 & 146.7 & 171118 \\
\hline 2014 & 398.6 & 256.6 & 141.8 & 155066 \\
\hline 2015 & 390.8 & 252.7 & 138.1 & 155955 \\
\hline 2016 & 388.0 & 248.7 & 139.3 & 161638 \\
\hline 2017 & 391.0 & 247.1 & 143.9 & 148323 \\
\hline
\end{tabular}

Source: own elaboration based on Central Statistical Office data (Rynek..., 2004, 2005, 2008, 2011, 2013, 2018; GUS, 2003; 2012b; GUS, 2007; 2010, 2012a; GUS, 2012-2018). 
and strawberries, while the area of fruit tree plantations, although fluctuating, did not change considerably. In turn, in recent years we have been observing a reduction in the area of fruit tree culture. Fruit production in Poland in 2017 was run on almost 400 thousand ha agricultural land, of which on approx. a half (46\%) apple trees were grown, with sour cherry trees accounting for $8 \%$, plum trees grown on $4 \%$, strawberries $13 \%$, raspberries $8 \%$, currants growing on $11 \%$ and approx. $1 \%$ area with gooseberry plantations (Rynek..., 2018).

Fruit production in Poland has been characterised by considerable fragmentation. Detailed data on the number of farms running orchards in individual area groups were presented in the data from the National Agricultural Census of 2002 and 2010 (GUS..., 2003; 2012b). In 2002 orchards were run on almost 317 thousand farms, with over $80 \%$ of these cultures covering less than 1 ha (Table 2). Similar results were recorded in 2010, as the number of farms running orchards dropped to approx. 264 thousand; still most of them (78\%) were orchards of less than 1 ha. In accordance with the new methodology applied by the Central Statistical Office (GUS..., 2014, pp. 42-43), since 2010 data concerning agricultural land have been given excluding owners of agricultural land, who do not run agricultural activity and owners of less than 1 ha agricultural land engaged in small-scale agricultural activity. In view of these changes, the number of farms running orchards published by GUS has also changed. The reports gave the number of farms with an area covered by orchards exceeding 1 ha, which owners were engaged in agricultural activity. In 2011 there were over 215 thousand farms (Table 1) and the number of farms running orchards decreased annually until 2014, when it was slightly over 155 thousand. In the following years the number of farms running orchards increased to over 161 thousand in 2016, whereas in 2017 there 148 thousand farms running orchards.

Detailed data on the number of orchards within individual area groups based on the Agricultural Censuses of 2002 and 2010 provided information on the considerable fragmentation of fruit production in Poland. A change in methodology applied by GUS and classification of some of these small orchards as home gardens did not erase them from existence. A home garden according to GUS (GUS..., 2014, p. 43) is "an area most frequently located next to the farm house (...). It covers the agricultural area cultivated to provide supplies primarily for the farm operator to satisfy the needs of their household. Occasional surplus may be sold. A home garden may comprise both agricultural crops and horticultural annuals, and perennial crops." This means that in the years of bumper fruit crops the surplus of fruit yields from home gardens may be sold on the market and be raw material for processing. Since they are frequently

Table 2. The number of farms running orchards in the area groups under orchards in Poland in the years 2002 and 2010

\begin{tabular}{lcccc}
\hline $\begin{array}{c}\text { The area groups } \\
\text { under orchards } \\
\text { (ha) }\end{array}$ & $\begin{array}{c}\text { The number of farms } \\
\text { running orchard } \\
\text { in } 2002\end{array}$ & $\begin{array}{c}\text { The share in total number } \\
\text { of farms running orchard } \\
\text { in } 2002(\%)\end{array}$ & $\begin{array}{c}\text { The number of farms } \\
\text { running orchard } \\
\text { in } 2010\end{array}$ & $\begin{array}{c}\text { The share in total number } \\
\text { of farms running orchard } \\
\text { in 2010 }(\%)\end{array}$ \\
\hline $\begin{array}{l}\text { Total } \\
316760\end{array}$ & 100 & 284556 & 100 \\
below 1 ha & 260389 & 82.2 & 222657 & 78.2 \\
$1-2$ & 25017 & 7.9 & 21057 & 7.4 \\
$2-5$ & 19822 & 6.3 & 23738 & 8.3 \\
$5-10$ & 8349 & 2.6 & 11481 & 4.0 \\
$10-15$ & 2080 & 0.7 & 3176 & 0.3 \\
$15-20$ & 557 & 0.2 & 992 & 0.2 \\
$20-30$ & 308 & 0.1 & 605 & 0.1 \\
$30-50$ & 144 & 0.05 & 375 & 0.2 \\
50 and more & 94 & 0.03 & 485 & 0.2 \\
\hline
\end{tabular}

Source: own elaboration based on GUS, 2003; $2012 b$. 
extensive cultures, characterised by low inputs into fruit production, the raw material obtained from such small home orchards was burdened with low production costs. Assuming that crops of these fruits are harvested thanks to surplus labour force of the farmer's family members, even low purchase prices paid by processors do not discourage these farmers from delivering this surplus of fruit to collection centres. This is an advantageous situation for fruit and vegetable processing in Poland, since it provides cheap raw material; however, it is disadvantageous for producers engaged in commercial fruit production, since in the years with bumper crops fruits non-commercial orchards may compete with commercial ones for deals with processors.

\section{RELATIONSHIPS BETWEEN FRUIT GROWERS AND PROCESSORS IN THE SUPPLY CHAIN OF RAW MATERIALS FOR PROCESSING}

The supply chain is a network of materials, information, and services processing links with the characteristics of supply, transformation, and demand (Chen and Paulraj, 2004). A characteristic feature of the supply chain is observed in the interdependence (an economic relationship) between companies and successive processes, based on the flow of streams of products, money and information. The aim of the establishment of this relationship is to improve efficiency of the entire system and its individual elements by alleviating the conflict of interests observed between partners in that chain (Dybowski and Kobuszyńska, 2009).

Generally speaking the relationship reflects interactions between two or more entities. The concept of economic relationships was defined as a manner of interactions taking place between the company and its contractors and other organisations as well as mutual dependencies of their behaviour in time (Dybowski and Kobuszyńska, 2009, after Ford, 2003).

Economic relationships may vary in type. Fischer et al. (2008) mentioned competitive relationships, relationships consisting in cooperation and those of a command economy. Competitive relationships are characterised by a zero-sum outcome: profit of one of the partners is connected with a loss of the other partner. Cooperationtype relationships are focused on mutual benefits for the partners. Conflicts are minimised and independence of the business partners is fostered. In a command economy relationship the supplier may enforce a dependence of the contractor by offering a unique product or service, or the contractor may have a greater bargaining power resulting from the unique or dominant access to a specific market. The avoidance of opportunism is the main incentive that governs the choice of a command relationship strategy.

Relationships between producers of agricultural raw materials and agri-food processors have been investigated in other studies. Principles for the selection of contractors and suppliers of raw materials based on a fruit and vegetable processing plant were shown by Kowalska (2003). In turn, Gołębiowski (2009) analysed conditions for vertical integration in the context of transaction costs, while he also mentioned price volatility on the fruit for processing as a barrier for the development of vertical integration. An attempt to identify factors for the development of vertical integration among organic food producers was made by Nasalski (2006), who indicated factors stimulating and limiting development of individual elements in the distribution chain. The stimulating factors are: reducing market risk (price stabilization) for agricultural holdings and stability of supply and the ability to impact the quality of the raw materials for processing. The limiting factors include the ability to dominate by processors, small production scale, the territorial dispersion of fruit production, the ability to import raw materials at great prices. Similar problems concerning the market of pigs for slaughter and relationships between farmers and processors were discussed by Mroczek (2003), while a benefits resulting from cooperation of meat processing plants with groups of producers (such as guaranteed supplies continuity and stability and high quality of raw material) were indicated by Knoblauch and Kisiel (2003).

In turn, American literature on the subject (Grow et al., 2003) describes the operations of organisations, which role is e.g. provide services in negotiating contractual conditions and prices between various participants of the market, including fruit growers and processors. Negotiations conducted by such organisations aimed at assurance that the process of price negotiation takes place rather than assurance of the most advantageous price for the producers. As it was reported by Hueth and Marcoul (2002), negotiations had a slight direct effect on the price level, they were rather a useful process as a form of price establishment on the market burdened with a considerable level of uncertainty of 
supply and demand conditions, with negotiating organisations playing an important role in assuring viability of the contracts (their being a reasonable reflection of the market reality). The role and importance of organisations participating in the solution of problems related with the stabilisation of prices for agricultural and horticultural raw materials on the market were indicated e.g. by Campbell (2002) and Hogeland (2009).

Relationships in the supply chain of fruit for processing in Poland based on the analysis of functioning of the primary market for fruit in the Grójec region were characterised by Borowska and Rejman (2008). Although the primary sales channel for all fruit species was their sale through an intermediary, producers could see disadvantages of this form of sales, such as excessively high commissions collected by intermediaries (sometimes $1 / 3$ price), price volatility, with prices changed even on a daily basis, the dependence of the price paid by the intermediary on the amount of fruit supplied in a given day, a long period of waiting for the payment for sold fruit, frequently lasting several months, high quality requirements imposed by intermediaries and the resulting purchase of fruit in terms of two quality grades at the simultaneous lack of precise quality grade classification criteria. According to a study by Borowska and Rejman (2008), sale of fruit directly to processors was observed mainly among large-scale commercial producers of apples and sour cherries, while a too small scale of production caused problems when entering into cooperation with processing plants or execution of contacts for fruit supplies. Halicka (2003) also describes relationships between participants of the fruit supply chain in Poland. Survey conducted among fruit producers and processors indicate that the main factors leading to hold up problems that influence the behaviour and performance of the Polish fruit market include: significant fragmentation of production, weak position of farmers in settings transaction terms and low level of horizontal and vertical integration. Such issue as delayed payments, price instability and changing quality requirements characterise the producer-buyer relationships.

In the context of the relationships between fruit producers in Poland and processors in the fruit and vegetable industry we observe problems in the price of fruit for processing development. Factors affecting sale prices for raw materials on the agricultural markets were presented by Hamulczuk et al. (2012). He indicate, that prices of agricultural commodities are the result of the supply and demand, the biological and technical nature of agricultural production, inter-market relationship and the impact of macroeconomic factors. In turn, Piwowar (2008) indicated that the demand and supply situation is the factor determining the level of purchase prices for agricultural produce and he listed determinants of prices both on the demand and supply side. One of the factors related with supply is the volume of production of a raw material.

\section{MATERIAL AND METHODS}

The aim of the research was to study the dependence between the volume of fruit production in Poland and purchase prices of fruit for processing. These investigations cover the period of 2000-2017. The object of the study were the selected species of the fruits - intended to processing in Poland. The volume of fruit production harvested from the culture of apples, sour cherries, plums, raspberries, strawberries, black currants, red and white currants as well as gooseberries were determined based on the data of the Central Statistical Office (Rynek..., 2002-2018). Purchase prices of apple for processing, sour cherries for juice pressing, sour cherries for freezing, Węgierka plums for freezing, stemless strawberries for freezing, stemmed strawberries for extract production, black currants, red currants, gooseberries and raspberries were adopted based on data of the Department of Horticulture Economics IERiGŻ-PIB gathered from processing plants (Rynek..., 2004-2018).

The relationship between the volume of production for individual fruit species and purchase prices of fruit for processing was investigated applying correlation analysis. The relationship between pairs of variables $X$ (fruit production) and $Y$ (prices of fruit for processing) was studied by Pearson's correlation coefficient and Spearman's R index. Pearson's linear correlation coefficient measures the power of a linear relationship between two measurable traits $X$ and $Y$ (Ostaszewicz, 1998, p. 52). The application of Pearson's correlation requires the assumption of normal distribution of variables to be met. The Shapiro-Wilk W test was used in order to verify the hypothesis stating that the distribution of a given variable is a normal distribution (Table 3). In the case the rejection of a zero hypothesis stating that the distribution of a given variable is a normal distribution, to estimate the power and the direction of the 
Kierczyńska, S. (2019). Relationships between producers and processors in terms of fruit production and prices of fruits for processing in Poland. J. Agribus. Rural Dev., 4(54), 307-317. http://dx.doi.org/10.17306/J.JARD.2019.01159

Table 3. Relations between fruit production quantity and the prices of fruit for processing in Poland in the period 2000-2017

\begin{tabular}{|c|c|c|c|}
\hline $\begin{array}{l}\text { Variable } X \text {-amount } \\
\text { of production }\end{array}$ & $\begin{array}{l}\text { Shapiro-Wilk W test } \\
\text { of variable } X\end{array}$ & Variable $Y$-price & $\begin{array}{l}\text { Shapiro-Wilk } \mathrm{W} \text { test } \\
\text { of variable } Y\end{array}$ \\
\hline Harvests of apple & $\mathrm{W}=0.9693 p=0.7861$ & apple for processing & $\mathrm{W}=0.8823 p=0.0285$ \\
\hline \multirow[t]{2}{*}{ Harvests of sour cherries } & $\mathrm{W}=0.8208 p=0.0030$ & sour cherries for juice pressing & $\mathrm{W}=0.9534 p=0.4820$ \\
\hline & & sour cherries for freezing & $\mathrm{W}=0.8691 p=0.0171$ \\
\hline Harvests of plums & $\mathrm{W}=0.9336 p=0.2246$ & plums for freezing & $\mathrm{W}=0.8904 p=0.0392$ \\
\hline \multirow[t]{2}{*}{ Harvests of strawberries } & $\mathrm{W}=0.9659 p=0.7180$ & stemless strawberries for freezing & $\mathrm{W}=0.9578 p=0.5609$ \\
\hline & & $\begin{array}{l}\text { stemmed strawberries for extract } \\
\text { production }\end{array}$ & $\mathrm{W}=0.8975 p=0.0521$ \\
\hline Harvests of black currants & $\mathrm{W}=0.9168 p=0.1136$ & black currants & $\mathrm{W}=0.8543 p=0.0099$ \\
\hline Harvests of red currants & $\mathrm{W}=0.9399 p=0.2894$ & red currants & $\mathrm{W}=0.0817 p=0.0008$ \\
\hline Harvests of gooseberries & $\mathrm{W}=0.8749 p=0.0214$ & gooseberries & $\mathrm{W}=0.9121 p=0.0937$ \\
\hline Harvests of raspberries & $\mathrm{W}=0.8941 p=0.0455$ & raspberries & $\mathrm{W}=0.8953 p=0.0476$ \\
\hline
\end{tabular}

Source: own elaboration based on Central Statistical Office data and the Department of Horticulture Economics IERiGŻ-PIB data (Rynek..., 2004-2018).

relationship between the investigated variables Spearman's R correlation coefficient will be applied.

Both Pearson's correlation coefficient and Spearman's $\mathrm{R}$ correlation coefficient takes values from the range of $[-1,1]$. The sign of the correlation coefficient informs on the direction of the correlation and its absolute value - on the power of the relationship. In order to state the significance of Pearson's correlation coefficient Student's t-test with n-1 degrees of freedom was applied, while the significance of Spearman's R correlation coefficient was verified using Student's t-test with n-2 degrees of freedom (Stanisz, 1998).

\section{RESULTS}

Apples are the main fruit produced in Poland. Harvested yields of apples in the period 2000-2017 were increasing (Fig. 1) mainly thanks to the intensification of their production. Results of a representative study on orchards (GUS..., 2013; 2018), conducted in 2012 and 2017 indicate a considerable increase in stocking density of apple trees and increasing outlays on production and storage of these fruits. Although commercial production of apples in Poland is run mainly for the market of table fruit, a considerable proportion, as much as $36 \%$ this production is used in processing. Industrial processing uses apples obtained from thinning, as well as fruit of inferior quality, rejected during sorting and not suitable for sale as table fruit. Purchase prices of apples for processing are thus significant for apple producers, particularly in a situation when a large part of the harvested yield is of poor quality. Purchase prices of processing apples in the period 2000-2017 ranged from $0.17 \mathrm{PLN} / \mathrm{kg}$ in 2009 to 0.7 PLN/kg in 2017 (Fig. 1). The level of purchase prices of apples for processing was not strongly related with the volume of fruit harvests in Poland. The correlation coefficient was -0.41 (Table 4 ), which indicates an average level of correlation, while the negative sign shows that the increase in apple harvest was accompanied by a decrease in purchase prices of apples for processing. The relationship between the volume of apple production and purchase prices of apples for processing was statistically non-significant at $p<0.05$. Results of earlier studies by this author (Kierczyńska, 2015) indicate that the level of purchase prices of apples for processing was also connected with e.g. export prices for condensed apple juice, as well as the volume of its production and export.

Harvests of sour cherries in the analysed period of 2000-2017 fluctuated most frequently around 150-200 thousand tons, never to exceed 200 thousand tons (Fig. 1). Purchase prices for freezing sour cherries were 
Kierczyńska, S. (2019). Relationships between producers and processors in terms of fruit production and prices of fruits for processing in Poland. J. Agribus. Rural Dev., 4(54), 307-317. http://dx.doi.org/10.17306/J.JARD.2019.01159

Table 4. Correlations between fruit production quantity and the prices of fruit for processing in Poland in the period 2000-2017

\begin{tabular}{lcc}
\hline \multicolumn{1}{c}{ The variety of fruit for processing } & $\begin{array}{c}\text { Pearson's correlation } \\
\text { coefficient }(p)\end{array}$ & $\begin{array}{c}\text { Spearman's R correlation } \\
\text { coefficient }\left(^{*} p<0,05\right)\end{array}$ \\
\hline Apple for processing & $-0.4095(0.091)$ & -0.2029 \\
Sour cherries for juice pressing & $-0.5640(0.015)$ & $-0.6629^{*}$ \\
Sour cherries for freezing & $-0.7201(0.001)$ & $-0.6581^{*}$ \\
Plums for freezing & $-0.7575(0.000)$ & $-0.8002^{*}$ \\
Stemless strawberries for freezing & $-0.4936(0.037)$ & -0.4618 \\
Stemmed strawberries for extract production & $-0.5086(0.031)$ & -0.4116 \\
Black currants & $-0.4127(0.089)$ & -0.1374 \\
Red currants & $-0.6002(0.008)$ & $-0.5695^{*}$ \\
Gooseberries & $-0.2862(0.250)$ & -0.1606 \\
Raspberries & $0.3891(0.110)$ & $0.4811^{*}$ \\
\hline
\end{tabular}

Source: own elaboration based on Central Statistical Office data and the Department of Horticulture Economics IERiGŻ-PIB data (Rynek..., 2004-2018).

higher than those for sour cherries for juice pressing (to be used for extract production). The level of purchase prices both for freezing sour cherries and sour cherries for juice pressing was strongly correlated with the volume of sour cherry harvests (Table 4 ) and in both cases this relationship was statistically significant at $p<0.05$. Person's correlation coefficient in the case of freezing sour cherries was -0.72 , which indicated a very high correlation, whereas in the case of sour cherries for juice pressing the value of this coefficient was lower, amounting to -0.56 , which indicates a high correlation. The negative sign of the correlation coefficient indicates that the increase in sour cherry harvests was accompanied by a reduction of purchase prices both for freezing sour cherries and sour cherries for juice pressing.

Harvests of plums in Poland were decreasing in the period 2000-2017 (Fig. 1). On average they amounted to 100 thousand tons, with the lowest harvest recorded in 2017 (60 thousand tons), while it was highest in 2001 and 2004 (132 thousand tons). Purchase prices for Węgierka plums for freezing ranged from $0.4 \mathrm{PLN} / \mathrm{kg}$ in 2004 and 2006 up to 2 PLN/kg in 2017 and they were strongly correlated with the volume of plum harvests (Table 4). Person's correlation coefficient was negative and amounted to -0.77 , which indicates a very high correlation and this suggests that a decrease in plum yields in Poland was accompanied by an increase in purchase prices of these fruits for processing.

Strawberries are a fruit species produced for the market of table fruit and they are a valuable raw material for processing. In Poland strawberries for processing have a high share in the production structure of these fruits. The volume of strawberry yields in the period 2000 2017 most frequently ranged from 150 to 200 thousand tons, with record yields obtained in 2001 (242 thousand tons). Purchase prices both for freezing strawberries and strawberries for extract production were in that year the lowest, amounting to $0.98 \mathrm{PLN} / \mathrm{kg}$ and $0.6 \mathrm{PLN} / \mathrm{kg}$ (Fig. 2). In all the years of the investigated period purchase prices for stemless strawberries for freezing were higher than those of stemmed strawberries for extract production due to higher costs incurred for harvesting stemless raw material. The relationship between the volume of strawberry harvests in Poland and purchase prices both for stemless and stemmed strawberries was rather strong (Table 4); however, a high correlation was found only in the case of stemmed strawberries $(-0.51)$, while for stemless strawberries they were recorded at an average level $(-0.48)$. In both cases Pearson's correlation coefficient was statistically significant at $p<0.05$ (Table 4).

The volume of black currant harvests ranged from 93 thousand tons in 2000 to over 154 thousand tons 

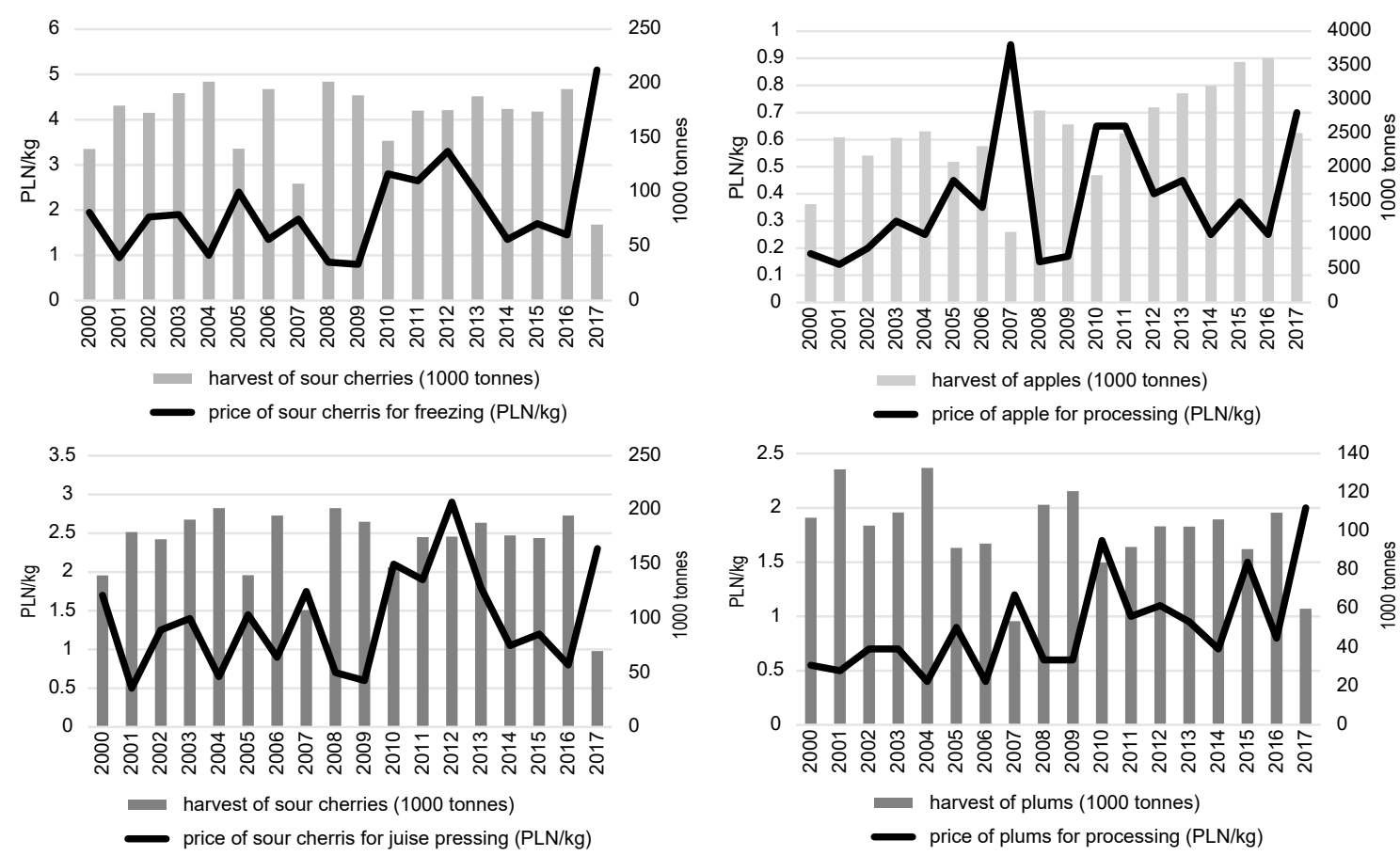

Fig. 1. Prices of apple, sour cherries and plum for processing and amount of these fruit production in Poland in 2000-2017

Source: own elaboration based on Central Statistical Office data and the Department of Horticulture Economics IERiGŻ-PIB data (Rynek..., 2004-2018).

in 2013, to decrease from year to year in the successive period (Fig. 2). Purchase prices for black currants were negative, but relatively weakly correlated with the volume of harvests. Person's correlation coefficient amounted to -0.41 and indicated an average correlation (Table 4). It was also statistically non-significant at the assumed significance level $p<0.05$.

Harvests of red currants were approx. three-fold lower than those of black currants and decreased in the analysed period from 56 thousand tons in 2001 to 30 thousand tons in 2017 (Fig. 2). Purchase prices for red currants ranged from $0.75 \mathrm{PLN} / \mathrm{kg}$ in 2005 to 4.3 PLN/kg in 2017, while the relationship between purchase prices for these fruits and the volume of harvests was strong (Table 4). Pearson's correlation coefficient amounted to -0.60 indicating a high correlation and it was statistically significant at $p<0.05$. This means that a decline in red currant harvests was accompanied by an increase in purchase prices of fruit for processing.
Gooseberries are a fruit species, which harvests decreased three-fold in the analysed period from almost 30 thousand tons in 2001 to 10 thousand tons in 2017 (Fig. 2). In turn, the level of purchase prices for gooseberries, despite a continuous decrease in harvests of these fruits, fluctuated considerably in the analysed years from 3.4 PLN/kg in 2003 to $0.75 \mathrm{PLN} / \mathrm{kg}$ in 2005 . Person's correlation coefficient between the volume of gooseberry harvests and purchase prices for processing fruit was negative and amounted to -0.29 (Table 4), indicating a weak relationship between the investigated parameters. It was statistically non-significant at $p<0.05$.

Raspberry harvests increased in the analysed period from slightly below 40 thousand tons in 2000 to 129 thousand tons in 2016 (Fig. 2). The increase in the volume of raspberry harvests in Poland was caused, among other things, by a considerable demand for the fruit for processing. An increase in the raspberry harvests was relatively weakly correlated with the fluctuations in 

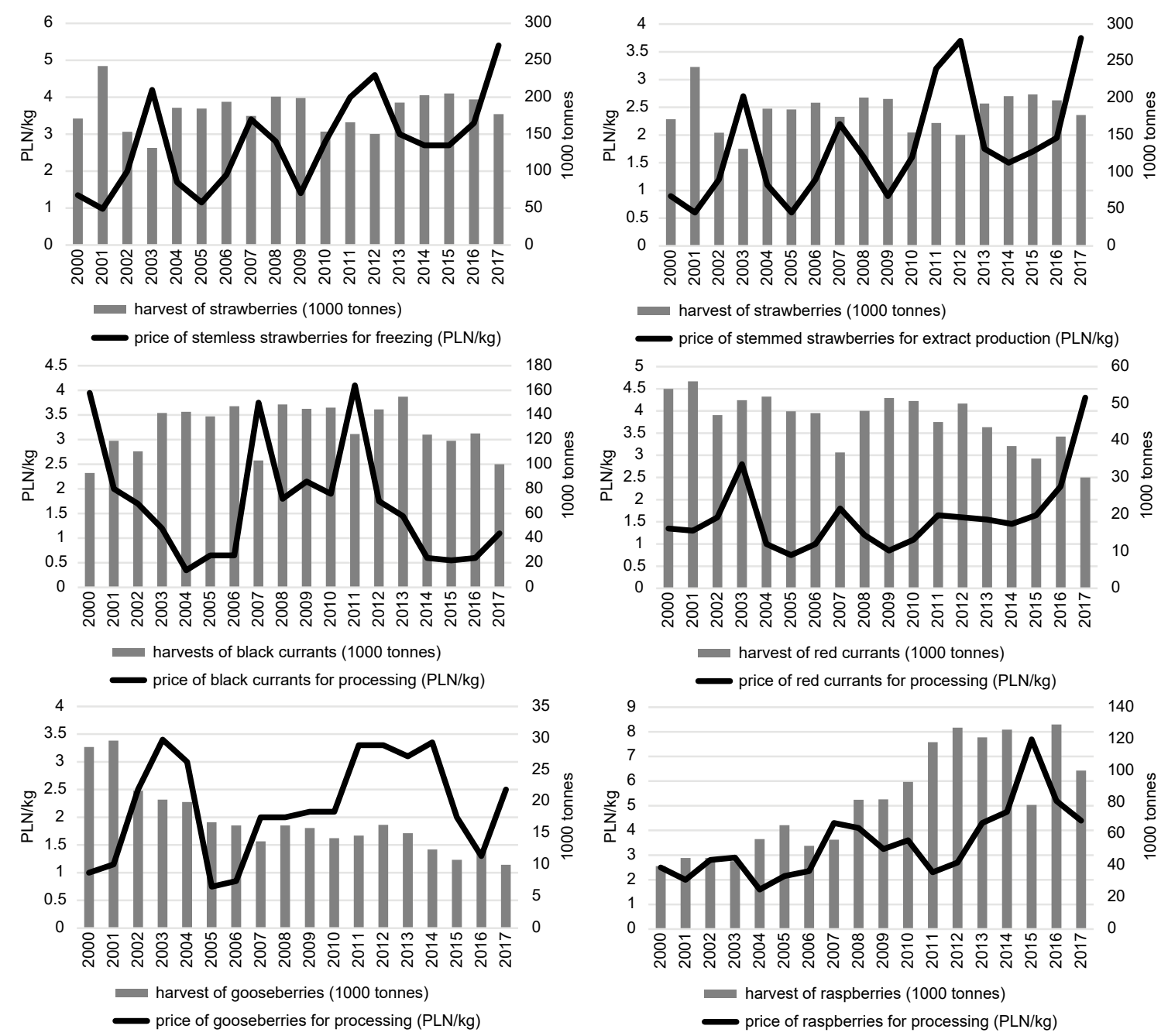

Fig. 2. Prices of strawberries, currants, gooseberry and raspberry for processing and amount of these fruit production in Poland in 2000-2017

Source: own elaboration based on Central Statistical Office data and the Department of Horticulture Economics IERiGŻ-PIB data (Rynek..., 2004-2018).

purchase prices of raspberries for processing. Pearson's correlation coefficient was positive in this case, indicating that an increase in raspberry harvests was also accompanied by an increase in purchase prices of the fruit for processing (Table 4). The value of the correlation coefficient amounting to 0.38 indicated an average power of the relationship between the investigated parameters, while Student's t-test indicated a lack of significance for this relationship at $p<0.05$.

The negative value of correlation coefficients between the harvest of fruits and the prices of most of the fruits for processing in Poland indicate that the increase in those fruits harvests were accompanied by reduction of their purchase prices. Moreover, the strong and significant correlation between the amount of the production of the fruits and the prices of fruits for processing means that the supply of fruits may be an important factor affected the prices of fruits for processing. The positive value of correlation coefficient between the volume of raspberry harvest and purchase price of raspberry for processing suggests that the other factors (e.g. demand factors) affected the price of raspberry for processing. 
Kierczyńska, S. (2019). Relationships between producers and processors in terms of fruit production and prices of fruits for processing in Poland. J. Agribus. Rural Dev., 4(54), 307-317. http://dx.doi.org/10.17306/J.JARD.2019.01159

\section{CONCLUSIONS}

1. On the basis of statistical data on the area of fruit production and the number of farms with orchards in Poland, it can be concluded that a characteristic feature of fruit production in Poland is still considerable fragmentation of production and stable (not changing over a long period) fruit growing area.

2. Based on the literature review, among the factors important in the supply chain, in relationships between producers of agricultural raw materials and processing can be mentioned: price volatility of the fruit for processing, small production scale, requirement of stable supply, and the ability to impact the quality of the raw materials for processing.

3. The fragmentation of fruit production in Poland makes the small scale of fruit production contributes to the poor (the underlying) fruit growers ' position in the supply chain of fruit for processing. For that reason the fruit producers must accept the terms of the sale and the price of fruits determined by fruit processing industry.

4. The price for most (aside from the raspberries) species of fruit for processing in Poland were negative correlated with the amount of production while the negative sign shows that the increase in fruit harvest was accompanied by the decrease in purchase price of fruit for processing. The results suggest fruit growers the opportunity of impact on price of fruit for processing by controlling the volume of fruit harvest.

5. The price of sour cherries, plums, strawberries and red currants for processing were strongly and significant correlated with the amount of the production of those fruits. The result suggests that the supply of mentioned species of fruits could be the important factor affecting the price of those fruits for processing.

6 . In view of the risk accompanying of fruit production, related to the inability of planning the output and the weak fruit grower's position the rational State policy should be conducted towards to guarantee fruit producers selling at least part of their fruit harvest at the reasonable price, and to provide processors possibility to make a supply of cheap raw material when the fruit harvest is plentiful.

\section{SOURCE OF FINANCING}

Research potential of the Department of Law and Organization of Enterprises in Agribusiness.

\section{REFERENCES}

Borowska, A., Rejman, K. (2008). Organizacja rynku pierwotnego owoców na przykładzie rejonu grójeckiego. [Organisation of the primary fruit market in the Grójec region]. Zesz. Nauk. SGGW Warsz. Probl. Roln. Świat., 4(19), 65-74 [in Polish].

Campbell, D. (2002). Unstable farm markets prompt more growers to look to bargaining co-ops. Retrieved from: https://www.thefreelibrary.com/Unstable+farm+markets + prompt + more + growers + to + look + to + bargaining + co-ops $-\mathrm{a} 090868268$

Chen, I. J., Paulraj, A. (2004). Towards a theory of supply chain management: the construct and measurements. J. Oper. Manag., 22, 119-150.

Dybowski, G., Kobuszyńska, M. (2009). Relacje ekonomiczne w europejskich łańcuchach żywnościowych. [Economic relationships in European food chains]. Zagad. Ekon. Roln., 1(318), 38-56 [in Polish].

Fischer, M., Hartmann, M., Bavorova, M., Hockmann, H., Suvanto, H., Viitaharju, L., Leat, P., Rovoredo-Giha, C., Henchion, M., McGee, C., Dybowski, G., Kobuszynska, M. (2008). Business relationships and B2B communications in selected European agri-food chains - first empirical evidence. Int. Food Agribus. Manag. Rev., 11(2), 73-100.

Gołębiowski, B. (2009). Partnerstwo wertykalne jako model powiązań gospodarstw rolnych z przetwórstwem. Rocz. Nauk Roln. Ser. G, 96(3), 302-310 [in Polish].

Grow, S., Guptill, A., Lyson, Th. A., Welsh, R. (2003). Apple industry study shows value of producer bargaining associations. Rural Coop., 70(5), 6-7.

GUS (2003). Uprawy ogrodnicze - Powszechny Spis Rolny 2002 [The National Agricultural Census 2002 - Horticultural crops]. Warszawa: GUS [in Polish].

GUS (2007, 2010, 2012a, 2014). Rocznik Statystyczny Rolnictwa [Statistical Yearbook of Agriculture]. Warszawa: GUS [in Polish].

GUS (2012b). Uprawy ogrodnicze - Powszechny Spis Rolny 2010 [The National Agricultural Census 2010 - Horticultural crops]. Warszawa: GUS [in Polish].

GUS (2012-2018). Użytkowanie gruntów i powierzchnia zasiewów [Land use and sown area]. Warszawa: GUS [in Polish].

GUS (2013). Produkcja ogrodnicza. Badanie sadów w 2012 [Horticultural production. Statistical survey of orchards in 2012]. Warszawa: GUS [in Polish].

GUS (2018). Produkcja ogrodnicza. Badanie sadów w 2017 [Horticultural production. Statistical survey of orchards in 2017]. Warszawa: GUS [in Polish]. 
Halicka, E. (2003). Links between Participants of the Fruit Supply Chain - Case study Poland. Acta Hort. 604, 293-298.

Hamulczuk, M., Gądek, S., Klimkowski, C., Stańko, S. (2012). Prognozowanie cen surowców rolnych na podstawie zależności przyczynowych [Forecasting the prices of agricultural raw material]. Warszawa: IERiGŻ-PIB [in Polish].

Hogeland, J. (2009). Co-ops facing challenges of global supply-chain economics. Rural Coop., 76(1), 4-7.

Hueth, B., Marcoul, Ph. (2002). Observations on Cooperative Bargaining in U.S. Agricultural Markets. Working Paper 02-WP 316, Center for Agricultural and Rural Development, Iowa State University.

Knoblauch, L., Kisiel, R. (2003). Korzyści zakładów mięsnych wynikające ze współpracy z grupami producenckimi [Benefits of meat factories from their cooperation with producer groups]. Rocz. Nauk. SERiA, V(2), 94-98 [in Polish].

Kierczyńska, S. (2015). Produkcja, eksport i ceny zagęszczonego soku jabłkowego a ceny skupu jabłek do przetwórstwa w Polsce [The relationship between production quantity, export and prices of apple juice concentrate and the prices of apple for processing in Poland]. Rocz. Nauk. Ekon. Roln. Rozw. Obsz. Wiej., 102(4), 74-81 [in Polish].

Kowalska, A. (2003). Problemy organizacji bazy surowcowej na przykładzie zakładu przetwórstwa owocowo-warzywnego Pudliszki S.A. [Selected problems of organization a stock base on the example of fruit and vegetable processing works Pudliszki S.A.]. Rocz. Nauk. SERiA, V(2), 109-113 [in Polish].
Mroczek, R. (2003). System powiązań między producentami a zakładami przetwórczymi na rynku żywca wieprzowego [Links between producers and processing industry on the life pig market]. Roczniki Naukowe SERiA, V(2), 147-151 [in Polish].

Nasalski, Z. (2006). Integracja pionowa producentów żywności ekologicznej [Verticale integration of producer of ecological food]. Rocz. Nauk. SERiA, VIII(2), 145-149 [in Polish].

Ostasiewicz, W. (Ed.). (1998). Statystyczne metody analizy danych [Statistical methods of analysis]. Wrocław: Wyd. A.E. im. Oscara Langego we Wrocławiu [in Polish].

Piwowar, A. (2008). Przestrzenne zróżnicowanie skupu produktów rolnych $\mathrm{w}$ Polsce. [Spatial diversification of procurement of agricultural products in Poland]. Rocz. Nauk Roln. Ser. G, 95(2), 89-96 [in Polish].

Rynek owoców i warzyw. Raporty rynkowe [Fruit and vegetable market. Market reports]. (1999-2018). Warszawa: IERiGŻ-PIB, ARR, MRiRW [in Polish].

Stanisz, A. (1998). Przystępny kurs statystyki [Accesible course of statistics]. Kraków: StatSoft [in Polish].

Wiśniewska, J. (2011). Konkurencyjność przedsiębiorstw przemysłu owocowo-warzywnego [Competitiveness of companies from the fruit and vegetable sector]. ZER, 2, 78-97 [in Polish].

Worley, T., Folwell, R., Foltz, J., Jaqua, A. (2000). Management of a cooperative bargaining association: a case in the Pacific Northwest asparagus industry. Rev. Agric. Econ., 22(2), 548-565. 